\title{
A Comparative Study between Pre-construction and Construction Phases of Champhai-Zokhawthar Road Construction, Mizoram: Air Quality and Noise Quality Assessments
}

\author{
Lalventluanga $^{1 *}$ and $\mathrm{H}$. Lalramnghinglova ${ }^{2}$ \\ ${ }^{1,2}$ Department of Environmental Science, Mizoram University, Aizawl-796004, Mizoram, India \\ E-mail: *venalushai@gmail.com
}

\begin{abstract}
In recent years, Mizoram has made immense progress in various sectors and initiated developmental programmes for its economic growth. An important contributing factor to this development and growth is the transport connectivity projects. Although connectivity projects can boost economic growth, its negative effects cannot be neglected. In view of this, the present research studies the impacts of Champhai - Zokhawthar road construction on the air quality and noise quality of the region. This comparative study of the impact on the quality of air and noise pollution in the pre-construction phase and construction phase provide a clear-cut example of the negative impacts caused by road construction and provide a fresh outlook for formulation of improved management plans. Air quality assessment was carried out using High Volume Air Sampler and the following parameters were monitored - suspended particulate matter (SPM), respirable suspended particulate matter (RSPM), nitrogen dioxide $\left(\mathrm{NO}_{2}\right)$ and sulphur dioxide $\left(\mathrm{SO}_{2}\right)$. The results indicate that mean SPM concentration was increased by $22.82 \mu \mathrm{g} / \mathrm{m}^{3}$; RSPM concentration by $14.67 \mu \mathrm{g} / \mathrm{m}^{3} ; \mathrm{NO}_{2}$ concentration by $4.08 \mu \mathrm{g} / \mathrm{m}^{3}$; and $\mathrm{SO}_{2}$ concentration was increased by $0.06 \mu \mathrm{g} / \mathrm{m}^{3}$ from the pre-construction phase to construction phase. Noise quality assessment was carried out at three sites - Zotlang, Melbuk and Zokhawthar by using Lutron SL-4001 Sound Level Meter and Leq, Lmax and Lmin were recorded and calculated. The mean noise level at Zotlang wasincreased by $8.72 \mathrm{~dB}(\mathrm{~A})$ and at Melbuk the mean noise level was increased by $9.35 \mathrm{~dB}$ (A). However, at Zokhawthar, there was a decrease in mean noise level by $0.13 \mathrm{~dB}(\mathrm{~A})$. From the present study, it is evident that road construction poses a threat to the air quality and noise quality of the study area and improved measuresneed to betaken to curb its negative impacts.
\end{abstract}

Keywords: Environmental Impact Assessment, Air Quality, Noise Quality, Road Construction, Champhai

\section{INTRODUCTION}

Roads are an integral part of the transport system and play an important role in the socio-economic growth of a community, state or nation. The overall performance and social functioning of a community is largely influenced by developed and maintained road networks. Roads enhance mobility, exposure from isolation and therefore poverty (Seiler 2001). The state ofMizoram hasalso made tremendous improvement in road infrastructure with Government of India taking initiatives to improve its road network in North-Eastern States of India. Mizoram being a state which greatly depends on roads for transportation will benefit immensely from these road improvement plans. Although the positive impacts of roads are greatly acknowledged, its negative impacts mainly to the environment are neglected and underestimated (Newman et al., 2012). Therefore, awareness on these negative impacts needs to be focused on with proper and effective mitigation measures before decision-making is done in any road construction project.

Road construction activities include land clearing, operation of machines and wide scale demolition works which generate high levels of dust which can disperse over long distances if not properly monitored (Gray, 2018). Such heavy machineries and vehicles emit a variety of pollutants- carbon dioxide, carbon monoxide, oxides of nitrogen, oxides of Sulphur, particulate matter, hydrocarbons and heavy metals, 
all of which have serious effects on flora, fauna and people. Stunted growths in plants near highways, photosynthetic and catalytic complexities, and even abrupt increase in species composition have been recorded (Spellerberg and Morrison, 1998). Emission of dust and other particulate matter have a serious toll in people as it penetrates into the lungs and causes respiratory illness, asthma, bronchitis and even cancer. Besides dust generation, the most common effect of road construction is noise pollution since construction equipment and heavy machineries are operated daily for long durations of time. Exposure to high noise levels has been found to alter activity patterns in animals with increase in heart rate and production of stress hormones. In human beings, exposure to high noise levels associated with road construction work can adversely affect human health causing stress, sleep disturbance, high blood pressure and even hearing loss (Gray, 2018). These detrimental effects render effective monitoring of road construction activities mandatory.

Environmental Impact Assessment (EIA) is a widely employed and effective tool to check the degradation caused by developmental projects including road constructions. It is defined as the systematic identification and evaluation of the potential impacts (effects) of proposed project plans, programmes or legislative actions relative to the physical, chemical, biological, cultural and socio-economic components of the total environment (Canter 1996). EIA as a mandatory regulatory procedure originated in the early 1970s, with the implementation of the National Environmental Policy Act (NEPA) in the United States of America (Glasson et al., 2012). In India, the foundation of EIA was laid in 1976-77 and formalized when Government of India enacted the Environment (Protection) Act on $23^{\text {rd }}$ May 1986 (Mukherjee 2012).

In this study, the environmental impacts of road construction on air quality and noise quality are assessed to highlight the extent of degradation caused by the road project. The results generated are then compared with the baseline data of its pre-construction phase provided by EIA report of Champhai-Zokhawthar Road Construction 2014 by STUP Consultants Pvt. (Anon. 2014). The overall results obtained will provide useful information on the effects of air and noise pollution caused by road construction and hopefully prompt legislators to take necessary actions to reduce wildlife hazards and protect human environment.

\section{MATERIALS AND METHODS}

\section{STUdy Site}

Champhai is one of the eight Districts in Mizoram which came into existence in the year 1998. It is the third largest of the 8 (eight) districts in Mizoram in terms of size and population. The district lies in the eastern part of Mizoram between $93.21^{\circ} \mathrm{E}$ longitude and $23.26^{\circ} \mathrm{N}$ latitude (Mizoram District Profile 2017). It has $80 \mathrm{~km}$ long international boundary with Myanmar in the east and Myanmar border is about $8 \mathrm{~km}$ from the District headquarters Champhai. The district is bounded by Manipur state in the north, Serchhip District in the west and Aizawl District in the north-west. The minimum and maximum temperature is $0^{\circ} \mathrm{C}$ to $20^{\circ} \mathrm{C}$ during winter and $15^{\circ} \mathrm{C}$ to $30^{\circ} \mathrm{C}$ during summer (Census of India 2011).

The road construction and up-gradation of the Champhai - Zokhawthar road is a development project under the Mizoram State Roads Project - II (MSRP - II). It is an environmental category " $\mathrm{A}$ " developmental project as per World Bank Policy as well as Government of India (GOI), Ministry of Environment, Forest \& Climate Change (MoEF\&CC). The existing Champhai - Zokhawthar Road (C-Z Road) is $28.0 \mathrm{~km}$ long. The designed length of the road is $27.247 \mathrm{~km}$ including spur road (short road forming a branch from a longer road) of $2.53 \mathrm{~km}$ length. The Champhai -Zokhawthar Road passes through villages viz; Khankawn, Zotlang, Ruantlang, Mualkawi,Melbuk \& Zokhawthar. The road project map is depicted in Figure 1.

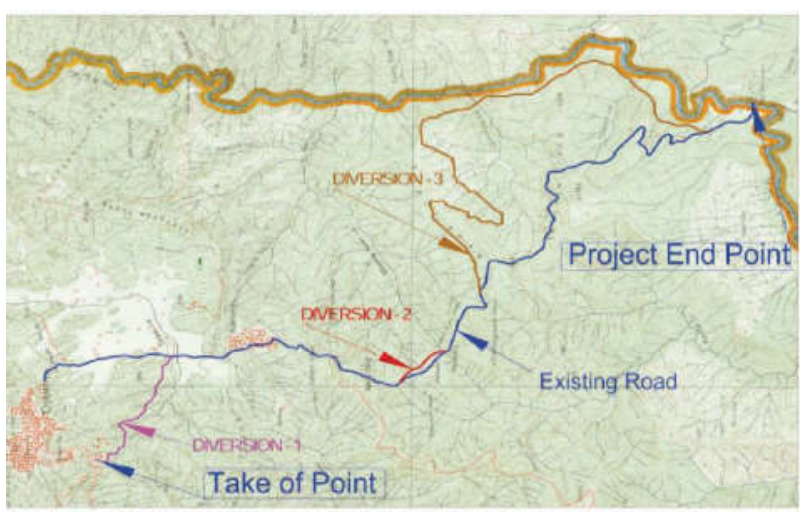

Fig. 1: Champhai to Zokhawthar Road Project Map Alongwith Diversions (Anon. 2014) 


\section{A Comparative Study between Pre-construction and Construction}

\section{Air QUALITY}

The ambient air quality was assessed at Zokhawthar village (main construction zone during assessment period) from September 2016 to August 2018 quarterly at 3 months interval employing High Volume Air Sampler. Sampling was carried out for 16 hours at a four hours interval from 6a.m to 10 p.m. The absorbing reagents and filter papers were then taken back to the laboratory for analysis. Handbook of Methods in Environmental Studies: Air, Noise, Soil and Overburden Analysis (Maiti 2003) and Manual on Environmental Analysis (Aery 2010) were mainly used for analysis of air quality parameters. Suspended Particulate Matter (SPM $>10 \mu \mathrm{m}$ ) was determined using highvolume method and the cyclonic flow technique was employed for determination of Respirable Suspended Particulate Matter $(\mathrm{RSPM}<10 \mu \mathrm{m})$. Jacob \& Hochheiser modified (sodium arsenide) method was used for determination of nitrogen dioxide, $\mathrm{NO}_{2}$ (Merryman et al., 1973)and the modified Westand Gaeke method was used for determination of Sulphur dioxide, $\mathrm{SO}_{2}$ (West and Gaeke 1956). The air quality parameters are then compared with the standards set by Central Pollution Control Board - National Ambient Air Quality Standards (NAAQS) vide Notification dated $11^{\text {th }}$ April 1994 (Central Pollution Control Board 1994) and National Ambient Air Quality Standards (NAAQS) vide Notification dated $18^{\text {th }}$ November 2009 (Central Pollution Control Board 2009).

\section{NOISE QUALITY}

Noise sampling was carried out at three sites i.e. Zotlang (Residential), Tarmat Base Camp (Residential area) and Zokhawthar (Residential area) from June 2016 to May 2018. The instrument used for sampling was Lutron SL-4001. The operational function of data recording was done by switching on the device at "A" weighing scale and "slow" response (CPCB 2015). The numerical values displayed on LCD were recorded. After recording of all the readings, Lmax, Lmin and Leq were calculated and the results were compared with the level of the standards of Noise Pollution (Regulation and Control) Rules 2000 (Ministry of Environment Forests \& Climate Change 2000).

\section{RESULTS AND DISCUSSION}

\section{Air QUALity}

Table 1: The Results for Air Quality Assessment and NAAQS

\begin{tabular}{|c|c|c|c|c|c|c|c|c|}
\hline \multirow{2}{*}{ Sampling Period } & \multicolumn{2}{|c|}{ SPM $\left(\mu \mathrm{g} / \mathrm{m}^{3}\right)$} & \multicolumn{2}{|c|}{$\operatorname{RSPM}\left(\mu \mathrm{g} / \mathrm{m}^{3}\right)$} & \multicolumn{2}{|c|}{$\mathrm{NO}_{2}\left(\mu \mathrm{g} / \mathrm{m}^{3}\right)$} & \multicolumn{2}{|c|}{$\mathrm{SO}_{2}\left(\mu \mathrm{g} / \mathrm{m}^{3}\right)$} \\
\hline & Mean & NAAQS & Mean & NAAQS & Mean & NAAQS & Mean & NAAQS \\
\hline Sept - Nov 2016 & 112.13 & \multirow{10}{*}{200} & 51.21 & \multirow{10}{*}{100} & 25.42 & \multirow{10}{*}{80} & 6.67 & \multirow{10}{*}{80} \\
\hline Dec - Feb 2017 & 162.12 & & 67.89 & & 31.26 & & 7.71 & \\
\hline Mar - May 2017 & 92.31 & & 28.65 & & 8.94 & & 5.32 & \\
\hline June - Aug 2017 & 76.18 & & 24.76 & & 11.92 & & 4.66 & \\
\hline Sept - Nov 2017 & 143.72 & & 71.26 & & 23.78 & & 5.88 & \\
\hline Dec - Feb 2018 & 133.78 & & 77.61 & & 14.34 & & 6.87 & \\
\hline Mar - May 2018 & 105.34 & & 31.02 & & 17.45 & & 4.45 & \\
\hline June - Aug 2018 & 121.04 & & 48.98 & & 15.56 & & 4.67 & \\
\hline Overall mean construction & 118.32 & & 50.17 & & 18.58 & & 5.76 & \\
\hline Overall mean pre-construction & 95.5 & & 35.5 & & 14.5 & & 5.7 & \\
\hline
\end{tabular}

The analysis of variance (ANOVA) showed that there was no significant variation in air quality between the seasons during the assessment period - 0.960 (at 5\%). The average SPM concentration ranged from 76.18 to $162.12 \mu \mathrm{g} / \mathrm{m}^{3}$ with a total mean concentration of $118.32 \mu \mathrm{g} / \mathrm{m}^{3}$. The average RSPM concentration ranges from 24.75 to $77.61 \mu \mathrm{g} / \mathrm{m}^{3}$ with a total mean concentration of $50.17 \mu \mathrm{g} / \mathrm{m}^{3}$. High SPM and RSPM concentration lead to increased dust generation which mainly consists of fumes, smoke and dust (ENVIS 2018); andhave deleterious consequencesin humans such as asthma attacks, bronchitis, high blood pressure, heart attack, strokes and premature death (Reddy et al., 2015). The 
average $\mathrm{NO}_{2}$ concentration ranges from 8.94 to $31.26 \mu \mathrm{g} / \mathrm{m}^{3}$ with a total mean concentration of $18.58 \mu \mathrm{g} / \mathrm{m}^{3}$. The average $\mathrm{SO}_{2}$ concentration ranges from 4.45 to $7.71 \mu \mathrm{g} / \mathrm{m}^{3}$ with total mean concentration of $5.76 \mu \mathrm{g} / \mathrm{m}^{3}$. High concentrations of $\mathrm{NO}_{2}$ and $\mathrm{SO}_{2}$ can cause damage to plant and materials, and cause complications in human respiratory system such as bronchitis (Chen et al., 2007).

Although the values of all calculated parameters in all seasons did not exceed the permissible limits of NAAQS for Residential areas at 24 hours sampling, the duration of exposure to such concentrations may prove detrimental to human health. Also, the concentrations of measured parameters peaked during the dry seasons (September-February) and showed lesser concentration during monsoon period (March-August). Dry conditions coupled with unmetalled roads produce heavy dust movements in the study area. Slope cutting and dumping of soil in nearby areas contributed immensely to the increase in concentration during the dry period. The seasonal variations of the measured parameters are shown in Figure 2.

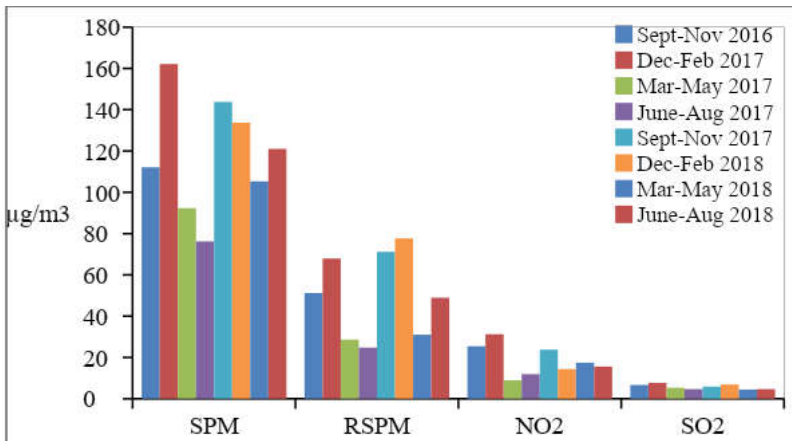

Fig. 2: Seasonal Variation of Air Quality Parameters

\section{COMPARISON OF AIR QUALITY BETWEEN Pre-Construction Phase AND Construction Phase}

Analysis of variance (ANOVA) shows there were no significant changes between the pre-construction phase and construction phase at $0.758(\mathrm{P}<0.05)$. However, the overall mean values show that the concentrations of the parameters have increased. The mean SPM concentration increased by a value of $22.82 \mu \mathrm{g} / \mathrm{m}^{3}$ i.e. $95.5 \mu \mathrm{g} / \mathrm{m}^{3}$ to $118.32 \mu \mathrm{g} / \mathrm{m}^{3}$, RSPM concentration increased by a value of $14.67 \mu \mathrm{g} / \mathrm{m}^{3}$ i.e. $35.5 \mu \mathrm{g} / \mathrm{m}^{3}$ to $50.17 \mu \mathrm{g} / \mathrm{m}^{3}, \mathrm{NO}_{2}$ concentration increased by a value of $4.08 \mu \mathrm{g} / \mathrm{m}^{3}$ i.e. $14.5 \mu \mathrm{g} / \mathrm{m}^{3}$ to $18.58 \mu \mathrm{g} / \mathrm{m}^{3}$ and $\mathrm{SO}_{2}$ concentration increased by a value of $0.06 \mu \mathrm{g} / \mathrm{m}^{3}$ i.e. $5.7 \mu \mathrm{g} / \mathrm{m}^{3}$ to $5.76 \mu \mathrm{g} / \mathrm{m}^{3}$. As mentioned earlier heavy dust movements mainly due to operation of heavy machineries for construction activities have rendered the area arenaceous and the air unclean. During sampling period many residents were spotted wearing masks and seen sprinkling water around the premises of their homes as a precautionary measure. Variation in air quality parameters between the two phases are depicted in Figure 3.

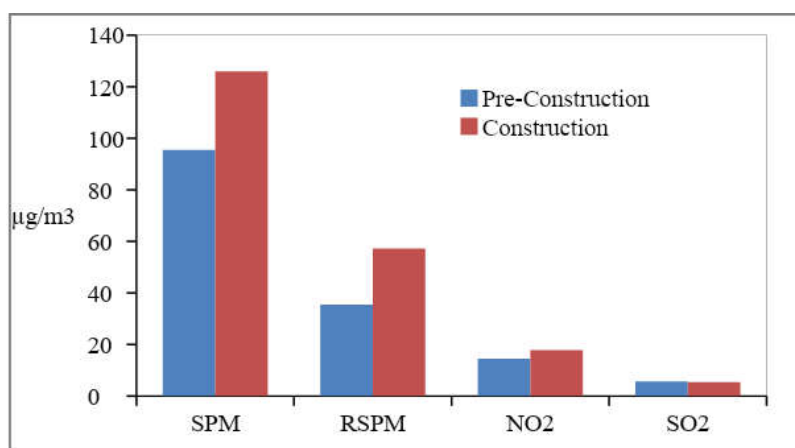

Fig. 3: Variation in Air Quality Parameters between the Pre-construction Phase and Construction Phase

\section{NoISE QUALITY}

Table 2: The Results for Noise Quality Assessment at Zotlang, Melbuk and Zokhawthar

\begin{tabular}{|c|c|c|c|c|c|}
\hline Season & Parameters & $\begin{array}{l}\text { Permissible Limit } \\
\text { (Residential) }\end{array}$ & Zotlang (dB) & Melbuk (dB) & Zokhawthar (dB) \\
\hline \multirow[t]{3}{*}{ Jun - Aug 2016} & Leq & \multirow{6}{*}{$55 \mathrm{~dB}$} & 75.3 & 57.8 & 58.3 \\
\hline & Lmax & & 78.3 & 60.4 & 59.8 \\
\hline & Lmin & & 45.4 & 42.7 & 46.1 \\
\hline \multirow[t]{3}{*}{ Sep - Nov 2016} & Leq & & 57.9 & 79.4 & 78.5 \\
\hline & Lmax & & 60.6 & 81.1 & 78.2 \\
\hline & Lmin & & 43.8 & 50.4 & 54.5 \\
\hline
\end{tabular}

Table 2 (Contd.).. 


\section{A Comparative Study between Pre-construction and Construction}

...Table 2 (Contd.)

\begin{tabular}{|c|c|c|c|c|c|}
\hline Season & Parameters & $\begin{array}{l}\text { Permissible Limit } \\
\text { (Residential) }\end{array}$ & Zotlang (dB) & Melbuk (dB) & Zokhawthar (dB) \\
\hline \multirow[t]{3}{*}{ Dec - Feb 2017} & Leq & \multirow{18}{*}{$55 \mathrm{~dB}$} & 64.5 & 70.9 & 74.1 \\
\hline & Lmax & & 66.6 & 71.9 & 76.6 \\
\hline & Lmin & & 54.3 & 55.2 & 49.6 \\
\hline \multirow[t]{3}{*}{ Mar - May 2017} & Leq & & 75.6 & 77.1 & 50.7 \\
\hline & Lmax & & 76.5 & 80.5 & 49 \\
\hline & Lmin & & 64.8 & 66.9 & 42.1 \\
\hline \multirow[t]{3}{*}{ Jun - Aug 2017} & Leq & & 74.1 & 59.7 & 52.8 \\
\hline & Lmax & & 76.3 & 60.7 & 54 \\
\hline & Lmin & & 60.7 & 48.8 & 42.1 \\
\hline \multirow[t]{3}{*}{ Sep - Nov 2017} & Leq & & 69.7 & 77.6 & 57.8 \\
\hline & Lmax & & 70.7 & 78 & 58.9 \\
\hline & Lmin & & 57 & 63.7 & 45 \\
\hline \multirow[t]{3}{*}{ Dec - Feb 2018} & Leq & & 69.6 & 76.9 & 65.1 \\
\hline & Lmax & & 69.5 & 76.3 & 66.5 \\
\hline & Lmin & & 56.3 & 63 & 44.8 \\
\hline \multirow[t]{3}{*}{ Mar - May 2018} & Leq & & 75.6 & 77.1 & 50.6 \\
\hline & Lmax & & 76.5 & 80.5 & 49 \\
\hline & Lmin & & 64.8 & 66.9 & 42.1 \\
\hline \multicolumn{2}{|c|}{ Overall mean Construction } & & 70.28 & 72.06 & 60.98 \\
\hline \multicolumn{2}{|c|}{ Overall mean Pre-Construction } & & 61.56 & 62.71 & 61.11 \\
\hline
\end{tabular}

ANOVA showed that there was no significant variation in noise quality between the seasons during the study period at $0.9(\mathrm{P}<0.05)$. At Zotlang area, the average noise level ranged from 57.9 to $75.6 \mathrm{~dB}(\mathrm{~A})$ with a mean value of 70.28 $\mathrm{dB}(\mathrm{A})$. At Melbuk area, the average noise level ranged from 57.8 to $79.4 \mathrm{~dB}(\mathrm{~A})$ with a mean value of $72.06 \mathrm{~dB}(\mathrm{~A})$. At Zokhawthar area, the average noise level ranged from 50.6 to $78.5 \mathrm{~dB}(\mathrm{~A})$ with a mean value of $60.98 \mathrm{~dB}(\mathrm{~A})$. The noise levels in the three study areas in all seasons exceeded the permissible limits as per the Noise Pollution (Regulation and Control) Rules 2000 except for Zokhawthar area.

Noise pollution usually do not cause direct impacts or losses, but rather indirect impacts causing problems and complications in humans and wildlife over a period of time, it is difficult to express its health effects as well as economic loss in a short period of time (Jacyna et al., 2017). Still, exposure to high noise levels can cause cardiovascular diseases and lead to acute or chronic changes of the physiological stress hormone regulation in humans (Ising and Kruppa, 2004) and a certain number of physiological and behavioural changes in birds (Bottalico et al., 2015). Seasonal variations in noise quality in the three assessment sites are shown in Figure 4.

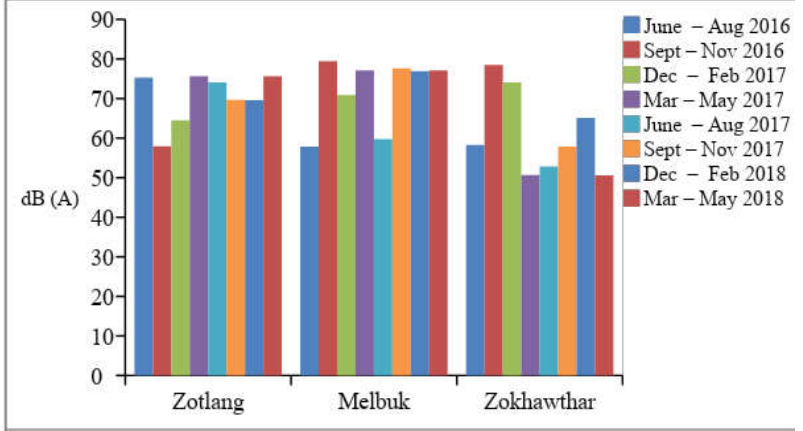

Fig. 4: Seasonal Variation of Noise Quality in the Three Sampling Sites

\section{COMPARISON OF NOISE QUALITY BETWEEN Pre-Construction Phase and Construction Phase}

ANOVA showed that there were no significant changes in noise level between pre-construction phase and construction phase at $0.18(\mathrm{P}<0.05)$. However, the overall mean noise level at Zotlang and Melbuk areas during construction phase is much higher in comparison to noise level during pre-construction phase. The mean noise level 
at Zotlang increased by $8.72 \mathrm{~dB}(\mathrm{~A})$ i.e. $61.56 \mathrm{~dB}(\mathrm{~A})$ to 70.28 $\mathrm{dB}(\mathrm{A})$ and at Melbuk the mean noise level increased by $9.35 \mathrm{~dB}(\mathrm{~A})$ i.e. $62.71 \mathrm{~dB}(\mathrm{~A})$ to $72.06 \mathrm{~dB}(\mathrm{~A})$. However, at Zokhawthar, there was a decrease in mean noise level by 0.13 $\mathrm{dB}(\mathrm{A})$ i.e. $61.11 \mathrm{~dB}(\mathrm{~A})$ to $60.98 \mathrm{~dB}(\mathrm{~A})$. Although Zotlang is a residential area, the diversion road cuts through the locality and noise is mainly detected from vehicles passing through the area as well heavy machinery operating in the area. The Contractor's base camp is located at Melbuk area and heavy machinery were continuously in construction during the study period. However, the mean noise level at Zokhawthar during construction phase is lower compared to the noise level during pre-construction phase which may be due to the fact that construction work/activities were inconsistent during study period and there was a halt in construction during rainy seasons. Variation in mean noise levels between the two phases are depicted in Figure 5.

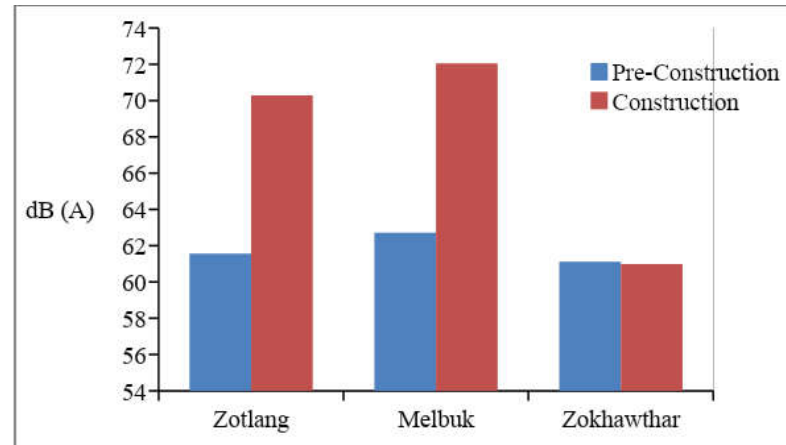

Fig. 5: Variation in Noise Quality between the Pre-Construction Phase and Construction Phase

\section{CONCLUSION}

The present study has revealed that the extensive use of heavy machinery and other construction equipment in road construction activities causes degradation to air quality as well as noise quality. Although environmental degradations are bound to occur during construction work, taking into account the baseline environmental conditions of the area, the level of degradation caused over a span of few years is notable. Alteration of landscape, topography and use of heavy machineries has led to air and noise quality degradation in the region. Taking into consideration the level of increase in air and noise pollution, better planning and proper execution of the construction work is imperative with strict implementation of mitigating measures proposed by environmental consultants and impact guidelines.
Therefore, the present study indicates the range of effects of road construction activities but the extent or magnitude of such effects still require more research. The ChamphaiZokhawthar road, in the near future will be an important gateway for trade and tourism for the country, therefore, it is mandatory to uphold and conserve the environmental stability of the area and minimize air and noise pollution to its permissible limits.

\section{REFERENCES}

Aery NC (2010) Manual on Environmental Analysis. $1^{\text {st }}$ Edn. Ane Books Pvt. Ltd., New Delhi.

Anonymous (2014) Environmental Impact Assessment Report for Widening to 2-lane, Re-alignment and Geometric Improvement of Champhai-Zokhawthar Road. Public Works Department, Government of Mizoram.

Anonymous (2014) Environmental Management Plan for Widening to 2-lane, Re-alignment and Geometric Improvement of Champhai-Zokhawthar Road. Public Works Department, Government of Mizoram.

Bottalico P, Spoglianti D, Bertetti CA, Falossi M (2015) Effect of Noise Generated by Construction Sites on Birds. In Burroughs C (edn). Implementing Noise Control Technology. $44^{\text {th }}$ International Congress and Exposition on Noise Control Engineering (InterNoise); Aug 9-12; San Francisco, California. Institute of Noise Control Engineering: Curran Associates Inc; pp. 1419 - 1425.

Canter LW (1996) Environmental Impact Assessment. $2^{\text {nd }}$ Edn. McGraw-Hill Inc., New York.

Census of India (2011) District Census Handbook: Champhai (2011). Directorate of Census Operations, Mizoram.

Cental Pollution Control Board (1994) National Ambient Air Quality Standards. CPCB, New Delhi.

Cental Pollution Control Board (2009) National Ambient Air Quality Standards. CPCB, New Delhi.

Cental Pollution Control Board (2015) Protocol for Ambient Level Noise Monitoring. CPCB, New Delhi.

Chen TM, Kuschner WG, Gokhale J, Shofer S (2007) Outdoor Air Pollution: Nitrogen Dioxide, Sulfur Dioxide, and Carbon Monoxide Health Effects. Am J Med Sci 333: 249-256.

Directorate of Economics and Statistics (2017) Mizoram District Profile 2017. Directorate of Economics and Statistics, Government of Mizoram.

ENVIS (2018) Suspended particulate matter. Ministry of Environment, Forests and Climate Change (MoEF\&CC); 2018 [cited 2018 Sept 23]. www.nbrienvis.nic.in.

Glasson J, Therivel R, Chadwick A (2012) Introduction to Environmental Impact Assessment. $4^{\text {th }}$ Edn. Taylor \& Francis Ltd, London.

Gray J. Pollution from construction. United Kingdom: Sustainable Build; 2018 [cited 2018 October 24]. http://www. sustainablebuild.co.uk/PollutionFromConstruction.html

Ising H, Kruppa B (2004) Health effects caused by noise: Evidence in the literature from the past 25 years. Noise Health 6: 5 - 13.

Jacyna M, Wasiak M, Lewczuk K, Karon G (2017) Noise and environmental pollution from transport: Decisive problems in developing ecologically efficient transport systems. J Vibroeng 19: 5639-5655. 


\section{A Comparative Study between Pre-construction and Construction}

Maiti SK (2003) Handbook of Methods in Environmental Studies, Volume 2: Air, Noise, Soil and Overburden Analysis. $1^{\text {st }}$ Edn. ABD Publishers, Jaipur.

Merryman EL, Spicer CW, Levy A (1973) Evaluation of arsenite modified Jacobs Hochheiser procedure. Environ Sci Technol 7: 1056-1059.

Ministry of Environment Forests \& Climate Change (2000) Noise Pollution (Regulation and Control) Rules. MoEF \& CC, New Delhi.

Mukherjee P (2012) EIA Scams: Decaying the EIA Legal Regime in India. J Environ Res Develop 6: 507 - 513.

Newman P, Hargroves C, DeshaC (2012) Reducing the Environmental Impact of Road Construction. Sustainable Built Environment National Research Centre, Australia.
Reddy YBR, Reddy SM, Reddy CBS (2015) Determination of Respirable Suspended Particulate Matter, Non Respirable Suspended Particulate Matter and Total Suspended Particulate Matter in Piduguralla Industrial Area India. Int Res J Environ Sci 4: 45-51.

Seiler A (2001) Ecological Effects of Roads. Swedish University of Agricultural Sciences (SLU), Uppsala.

Spellerberg IF, Morrison T (1998) The ecological effects of new roads: a literature review. Department of Conservation, Wellington, New Zealand.

West PW, Gaeke GC (1956) Fixation of SO2 as sulfi-tomercurate (II) and subsequent colorimetric estimation. Anal Chem 28: 1816-1819. 